Determinants of Online Repurchase Intention in Covid-19 Times: Evidence From an Emerging Economy

Aldo Alvarez-Risco, Liliana Quipuzco-Chicata, and Carlos Escudero-Cipriani 
Aldo Alvarez-Risco, Liliana Quipuzco-Chicata, and Carlos Escudero-Cipriani

\section{Determinants of Online Repurchase Intention in Covid-19 Times: Evidence From an Emerging Economy}

Abstract: COVID-19 has led to social isolation and a subsequent increase in online shopping has been observed. The present study is based on theory of reasoned action and focused on 371 Perwvian consumers, it seeks to evaluate the current effect of the website quality, customer satisfaction, and customer trust in online repurchases. The current study is cross-sectional and uses an online survey with 22 questions that evaluated consumers repurchase intentions. A technical SEM-PLS analysis was used. It was found that website quality had a positive influence on customer satisfaction, website quality positively influenced customer trust, customer satisfaction had a positive influence on customer trust, customer satisfaction had a positive influence on online repurchase intention, and customer trust had a positive influence on online repurchase intention. The model explained $20.6 \%$ of online repurchase intention behavior. Outcomes of the bootstrapping test were used to evaluate if path coefficients are significant. The outcomes can help companies to develop strategic plans to increase online purchasing. The novelty is based on using the partial least squares structural equation modeling (SEM-PLS) technique.

Keywords: Peru, COVID-19, repurchase intention, e-commerce, website quality, customer satisfaction, customer trust.

JEL Classification: C83, E21.

\section{Determinantes de la intención de recompra en línea en tiempos de COVID-19: evidencia de una economía emergente}

Resumen: Los tiempos de COVID-19 han generado aislamiento social en las personas ytambién - se ha incrementado la compra online. El presente artículo basado en el estudio en 371 consumidores peruanos busca evaluar el efecto actual de la calidad del sitio web, la satisfacción del cliente y la confianza del cliente sobre la recompra en línea. Fue un estudio transversal que utilizó una encuesta en linea. Veintidós preguntas evaluaron la intención de recompra de los consumidores. Se utilizó un análisis técnico SEM-PLS. Se encontró que la calidad del sitio web tuvo una influencia positiva en la satisfacción del cliente e influyó positivamente en la confianza del cliente; asimismo, la satisfacción del cliente tuvo una influencia positiva en la confianza del cliente y en la intención de recompra en linea; y la confianza del cliente tuvo una influencia positiva en la confianza en línea y la intención de recompra. El modelo explicó el 20,6\% de la intención de recompra online. Los resultados de la prueba de arranque se utilizaron para evaluar si los coeficientes de trayectoria son significativos. Los resultados pueden ayudar a las empresas a desarrollar planes estratégicos para aumentar las compras en linea. La novedad se basa en el uso de la técnica de modelado de ecuaciones estructurales de minimos cuadrados parciales (PLS-SEM).

Palabras clave: Perú, COVID-19, intención de recompra, comercio electrónico, calidad del sitio web, satisfacción del cliente, confianza del cliente.

\section{(cC) BY-NC-SA}

Este artículo y sus anexos se distribuyen por la revista Lecturas de Economía bajo los términos de la Licencia Creative Commons Atribución-NoComercial-CompartirIgual 4.0. https://creativecommons.org/licenses/by-nc-sa/4.0/ 


\section{Déterminants de l'intention de rachat en ligne en période de COVID-19: données probantes d'une économie émergente}

Résumé: Les temps de COVID-19 ont généré l'isolement social chez les gens. De même, les achats en ligne ont augmenté. Cet article basé sur une étude auprès de 371 consommateurs péruviens, cherche à évaluer l'effet actuel de la qualité du site Web, de la satisfaction de la clientèle et de la confiance des clients sur le rachat en ligne. Il s'agissait d'une étude transversale qui utilisait un sondage en ligne. Vingt-deux questions évaluaient l'intention de rachat des consommateurs. Une analyse technique SEM-PLS a été utilisée. Il a été constaté que la qualité du site Web avait une influence positive sur la satisfaction de la clientèle et avait une influence positive sur la confiance des clients; en outre, la satisfaction de la clientèle a eu une influence positive sur la confiance des clients et sur l'intention de rachat en ligne; et la confiance des clients a eu une influence positive sur la confiance en ligne et l'intention de rachat. Le modèle représentait 20,6\% de l'intention de rachat en ligne. Les résultats du test de démarrage ont été utilisés pour évaluer si les coefficients de trajectoire sont significatifs. Les résultats peuvent aider les entreprises à développer des plans stratégiques pour augmenter les achats en ligne. La nouveauté est basée sur l'utilisation de la technique de modélisation des équations structurelles des moindres carrés partiels (PLS-SEM).

Mots clés: Pérou, COVID-19, intention de rachat, e-commerce, qualité du site web, satisfaction du client, confiance du client.

\section{Cómo citar / How to cite this item:}

Alvarez-Risco A., Quipuzco-Chicata L., \& Escudero-Cipriani C. (2022). Determinants of Online Repurchase Intention in Covid-19 Times: Evidence From an Emerging Economy. Lecturas de Economia, 96, 101-143. https://doi.org/10.17533/udea.le.n96a342638 


\title{
Determinants of Online Repurchase Intention in Covid-19 Times: Evidence From an Emerging Economy
}

\author{
Aldo Alvarez-Risco $\oplus^{\mathrm{a}}$, Liliana Quipuzco-Chicata $\odot^{\mathrm{b}}$, and Carlos \\ Escudero-Cipriani ${ }^{\mathrm{c}}$
}

- Introduction. -I. Literature review. -II. Research model. -III. Methodology. -IV. Results. -V Discussion. -Conclusions. -References.

Original manuscript received on 28 June 2020; final version accepted on 20 June 2021

\section{Introduction}

Since December 2019, the world has been changed dramatically by the Coronavirus (COVID-19), an infectious disease of pandemic proportions, with approximately $128,000,000$ cases and 2.8 million deaths reported worldwide as of March 31, 2021 (WHO, 2021). The health system offers various services (Alvarez-Risco et al., 2018; Enciso-Zarate et al., 2016; LazoPorras et al., 2020; Mejía-Acosta et al., 2016) and information alternatives to citizens (Álvarez-Risco et al., 2013; Buttenheim et al., 2018) but the COVID19 pandemic has negatively impacted different societal actors such as health professionals (Chen et al., 2020; Rojas Román et al., 2020; Yáñez et al., 2020; Zhang et al., 2021; Zhang et al., 2020), tourism (Brouder, 2020; CarvacheFranco et al., 2021; Fotiadis et al., 2021), entrepreneurship (Acevedo-Duque et al., 2021; Afshan et al., 2021; Alvarez-Risco \& Del-Aguila-Arcentales, 2021; Chafloque-Cespedes et al., 2021), education (Allen et al., 2020; Alvarez-Risco, Estrada-Merino, Anderson-Seminario, et al., 2021; Daniel, 2020; Theoret \& Ming, 2020), prices (Apcho-Ccencho et al., 2021; Leiva-Martinez et al., 2021; Sharif et al., 2020), individuals (Al-Hasan et al., 2020; Alvarez-Risco et al.,

a Aldo Alvarez-Risco: Associate professor at Universidad de Lima.

E-mail: aralvare@ulima.edu.pe https://orcid.org/0000-0003-0786-6555

b Liliana Quipurco-Chicata: Associate professor at Universidad de San Martín de Porres.

E-mail: lquipuzcoc@usmp.pe https://orcid.org/0000-0002-5200-069X

c Carlos Escudero-Cipriani: Associate professor at Universidad de San Martín de Porres.

E-mail: cescuderoc@usmp.pe https://orcid.org/0000-0001-7377-5147 
2020; Machida et al., 2020; Quispe-Cañari et al., 2021; van Stekelenburg et al., 2021) and firms (Altig et al., 2020; Alvarez-Risco, Estrada-Merino, Rosen, et al., 2021; Duarte Alonso et al., 2020; Yan et al., 2021). In economic terms, the Peruvian economy was mainly affected by the high global unemployment rate (ILO, 2020). However, technology can be used to reactive the economy to reach a significant number of consumers.

According to Huarng and Yu (2011) and Evans (2019), the Internet is popular today and has allowed people and companies to make exchanges more efficient. Adapting to change will allow Peruvian companies to survive the COVID-19 pandemic and could lead to an increase in online repurchase intentions, as demonstrated by the analysis carried out by the Business Intelligence unit of Niubiz, which has recorded an almost $50 \%$ increase in average e-commerce consumption in Peru since March 16 to 27, 2020 to the present date.

In Peru, e-commerce has risen thanks to different initiatives, such as those developed by the Peruvian Chamber of Electronic Commerce (www.capece.org.pe), and the promotion of different forms of non-traditional electronic payment, for example, the use of applications created by banks ("Yape" or "Plin") which allows users to send and receive money from their mobile phones. Despite the increasing growth of electronic commerce, there are still some barriers for consumers, which are usually linked to security when delivering debit or credit card data and, therefore to user confidence in online transactions, regardless of the type of product (Belwal et al., 2020; Faraoni et al., 2019; Guo \& Gao, 2017; Huang \& Chang, 2019; Rahman et al., 2018; Sharma et al., 2019; Tandon et al., 2020; Valarezo et al., 2018; Zhu et al., 2019). According to the "Future Buy" (2018) study carried out by GfK named $39 \%$ of Peruvian consumers distrust product delivery processes, $55 \%$ are afraid important information will be misused, $22 \%$ prefer the brick-andmortar stores, and 40\% prefer to see products in person before buying them.

The current study investigates the link between the quality of websites where products or services to be purchased by the consumer are offered, regardless of the device used (laptop, desktop, mobile phone), to access the aforementioned pages online customer satisfaction, and customer trust in 
online shopping and their intention to continue buying certain products or services: repurchase. Repurchase intentions are the starting point for customer loyalty (Ahmad et al., 2016; Chiu et al., 2009; Das, 2014; Savila et al., 2019; Yi \& La, 2004). The customer's commitment to staying true to an online store is indicated by the intention to repurchase (Amoako et al., 2019; Chen \& Chen, 2017; Chou \& Chen, 2018; Pee et al., 2018; Sullivan \& Kim, 2018). The literature indicates that customer satisfaction is the fundamental basis for repurchase intention (Ashfaq et al., 2019; Fang et al., 2014; Fang et al., 2011; Trivedi \& Yadav, 2020; Wu \& Chang, 2007). However, other authors such as Dehghan (2015) have not found a significant effect in this relationship which a mediating variable between satisfaction and repurchase intention could explain. In the present study this mediating variable is presented as trust.

All of the aforementioned occurs in normal scenarios, in which people can physically go out and purchase products and decide to repurchase online; however, the current COVID-19 pandemic changes all of these preconditions and establishes another scenario: social isolation (Banerjee \& Rai, 2020; Berg-Weger \& Morley, 2020; Hwang et al., 2020; Razai et al., 2020). In this circumstance, people do not have the same ease of buying products on any day or at any time, and, additionally, the supply of products is restricted to those that are most necessary (food and medicine) (Gostin \& Wiley, 2020). Therefore, the need arises to identify the relationship between website quality, products ordered, consumer satisfaction, consumer confidence, and repurchase intention. The current study is carried out in Peru since the government's social isolation measures have led to increased online repurchasing.

Awareness of the relationships between these variables will allow online product and service providers to place more emphasis on the variables that generate the most significant impact. At the same time, this will lead to increased intentions on the part of consumers to allow them to repurchase their products via online channels. 
Alvarez-Risco, Quipuzco-Chicata, and Escudero-Cipriani: Determinants of Online...

\section{Literature review}

\section{A. Website quality}

There are different studies on website quality. For example, those carried out by Bai et al. (2008), Lee and Kozar (2006), Bai et al. (2008), Kim and Niehm (2009), Liang and Chen (2009), Wells et al. (2011), Wang et al. (2015) and Tandon et al. (2017). Also, the current pandemic and isolation generated an unprecedented increase in online purchasing worldwide (Gao et al., 2020). Therefore, the quality of companies' information on users becomes very important for purchasing decisions (Chen \& Chang, 2018; Gao et al., 2012; Park \& Kim, 2003). In addition to the usual website quality dimension, another crucial issue has become crucial for users: multiplatform access means easy access to the web from a desktop, laptop, or mobile phone (Singh \& Jang, 2020). This aspect has been the most complicated to work on since, in many cases, users are middle-aged (35-55 years) and may not be accustomed to reading information on their mobile phone screens. Previous studies show the positive relationship between website quality and customer satisfaction (Ahmad et al., 2017; Kaya et al., 2019; Li et al., 2017; Solimun \& Fernandes, 2018; Tandon et al., 2020). Through these studies, it is possible to see the influence that the quality of service has in predicting customer satisfaction and generating the intention for virtual repurchases. During the current COVID-19 pandemic, several companies that previously only offered in-person sales diversified to offer virtual sales (BBC, 2020), giving a visual and support offer to virtual purchase much higher than what was offered before the pandemic. This is a justifiable effort to attract new customers (with no or minimal virtual shopping experience) as well as to maintain existing current customers (Prasetyo et al., 2021).

For the authors, it is crucial to assess whether the information presented on the web at the time of offering a product or service is detailed, explaining each component in a way that is easy to understand and can even be saved to read calmly later, in the form, for example, of small online files or even short podcasts describing the benefits of the product (Rodríguez et al., 2018; Wang et al., 2019). Another element to be measured is how complete the information provided in the virtual offer is, which enables buyers to trust in 
the product and thereby rule out being surprised later with "small print" on the website that was not displayed on the original offer page (Liu \& Tang, 2018; Stouthuysen et al., 2018). A website should generate sufficient interest to inspire users to explore it, regardless of whether or not the they end up making a purchase at that time or not (Ventre \& Kolbe, 2020).

A user can clearly evaluate how interesting a webpage is. Additionally, complementary information that may be included on a website makes the purchase a comfortable and multisensory experience rather than a merely transactional one (Kang \& Namkung, 2019). There are hundreds of companies offering products on webpages, so it is necessary to understand the different innovations used on consumer websites. This is relevant because current customers will continue to buy from pages with constant innovations, whether this is in the form of new information, new promotions, interactions via crowdsourcing, or crowdfunding models with regular clients (Ma et al., 2019). Finally, and most importantly, a successful website needs to offer information that can be found in a simple, intuitive fashion regardless of whether it is being accessed through a desktop, tablet, or another device.

\section{B. Customer Satisfaction}

Customer satisfaction in the online environment can be conceptualized as the customer's evaluation after purchasing products or services from a website (Hsu, 2008; Lin et al., 2011; Shankar et al., 2003). During the pandemic, demand has been much higher due to the heightened anxiety that consumers experiences does not leave room for errors or delays in the delivery of the products that are purchased (Zhao et al., 2020). Achieving and maintaining customer satisfaction is a challenge for companies, which work to achieve a close bond that helps them understand customers' current and future needs. For this consumer-based study during the pandemic, the authors evaluated the following path: website quality $\rightarrow$ customer satisfaction $\rightarrow$ trust $\rightarrow$ repurchase intention (Liang et al., 2018).

For the current study, we have evaluated how much customers enjoy the online repurchase experience; in other words, that repurchases are made not only because a customer requires a product but also because the online 
shopping experience is pleasant. This makes it possible to demonstrate the hedonistic aspect of online repurchasing (Hellier et al., 2003; Meilatinova, 2021). Likewise, convenience, which is intimately related to social isolation, is evaluated. In many cases, online shopping has become the only way to obtain specific products, which are not physically available or have been sold out on face-to-face channels (Slack et al., 2020).

There is also an evaluation of the customers' opinion of how good the online repurchase decision is; There is also an evaluation of the customers' opinion of how good the online repurchase decision is, which allows companies to obtain personal data to send advertising of the products and services they offer. (Rastogi \& Mehrotra, 2017). Additionally, the fact that a company is familiar with clients' purchasing preferences and can offer preferential purchase notices as thanks for customer loyalty is taken into account (Ahani et al., 2019; Nguyen et al., 2019; Tan et al., 2018). Satisfaction is the cornerstone of knowing how a client feels that his/her needs are fully satisfied. This satisfaction can be generated via different components of online sales and can lead to customers trusting the company that offers products/services online. In other words, the expectation at the time of purchase coincides with the customer experience (Qazi et al., 2017).

\section{Customer Trust}

A significant percentage of customers have a low level of trust in online purchasing (Gestión, 2019). There are cases in which when a customer clicks on a link, a malicious application is installed on their phones to extract sensitive financial data. It is difficult for users to feel comfortable sending information online when these kinds of threats exist. This increased personal leads to less and less trust in providing information for purchases made online. It is difficult for users to feel comfortable sending information online when these kinds of threats exist. This increased personal information leads to less trust in providing information for online purchase which has increased very rapidly in times of COVID-19 as recently described by Alvarez-Risco et al. (2020). Mayer et al. (1995) establish that trust is the willingness of a first person to be vulnerable to a second person's actions based on the first person's 
expectation and regardless of the possibility to control the other party, which shows that the concept of trust is closely related to the online arena where we talk to people every day without hearing their voices or seeing their faces and, despite this, we trust in the exchange of information.

This study evaluates whether clients believe that companies have mechanisms to take care of their clients' data. In the instance of online purchases, it is interesting to note that frequently when customers make a virtual payment the receiving company issues an explicit message indicating that the operation is safe, while others do not indicate this even when they also are offer said transactional security (Berry et al., 2020; Jin et al., 2018). Another related component is that customers want to have direct trust, expressing that they feel that the company will be honest with them. This is not only related to the risks involved in making online payments but also, for example, to trusting that the product that arrives meets the specifications of the product shown at the time of purchase and that the delivery be made at promised time (Gawor \& Hoberg, 2019).

This perception of honesty is fed not only by the client's own experiences but also by their friends and family. Another element to be explored concretely is the client's security when paying, based on the payment alternatives; the best thing is that there is a link to a payment system such as SafetyPay or access to an online module certified by Visa. Customer's confidence is also measured regarding a company's ability to conduct business online. This is related to whether or not a company has a stable supply and payment system, that is, whether or not purchases can always be made without any inconvenience or doubt, which will result in the perception that the company is reliable and can also be reported by customers (Song et al., 2020).

\section{Repurchase Intention}

The repurchase intention in the context of online commercial transactions is a consumer's tendency to back to a website and consider purchasing products or services from the same online website or even app and his/her commitment to purchasing more in the future (Lim et al., 2019). In the 
present study, the intention to purchase is evaluated as an endogenous variable, based on the theory of reasoned action (Azjen, 1980), which states that intention is considered the best factor before the behavior and is appropriate for evaluating consumers' behavior. Also, Parasuraman et al. (1994) found that willingness to revisit a webpage shows a willingness to repurchase, recommend the page, and make positive comments to friends and family. In the literature, various studies such as those published by Liao et al. (2017), (Pee et al., 2018), Sullivan and Kim (2018), Pham et al. (2018), and Rojas-Osorio (2019) have evaluated customers' online purchase intention in different commercial sectors.. Curina et al. (2020) detailed the phenomenon of brand hatred, which may be motivated by different failures (times, costs, product damage, not meeting specifications, among others). These failings generate customer complaints online, negative word of mouth offline, and the nonrepurchase intention. This is very tangible since a series of complaints and messages about different types of products or services can be found on a daily basis. These range from the small to significant complaints specifically in the case of online purchases. Customer complains may take different forms, the most passive being the blog or Tweet, with more extreme cases seen in YouTube videos that can easily go viral.

The intention to continue shopping after compulsory social isolation in Peru will be evaluated and the study will also assess whether consumers intend to increase their online shopping activity. Additionally, it will also seek to measure whether consumers plan to purchase online or if they intend to return to physical stores. Another critical element to evaluate is customers' willingness to use their credit cards to purchase online since this represents the most significant risk. This indicator will enable us to see how much customers trust companies that offer products or services online. When trust is endorsed, and great confidence is achieved, happy customers will actively recommend the companies in questions to friends and family members thanks to their positive purchasing experiences, trust, and associated recommendation levels. Finally, will attempt to assess whether consumers who have been in social isolation have had a bad experience with online shopping and do not plan to buy again. 


\section{Research model}

We determine the influence of the website's quality, mediated by customer satisfaction and customer confidence, on Peruvian consumers repurchase intentions during the COVID-19 pandemic. According to Shin et al. (2013), website quality is an essential factor for predicting online purchasing. The four constructs are shown in Figure 1.

Figure 1. Research model

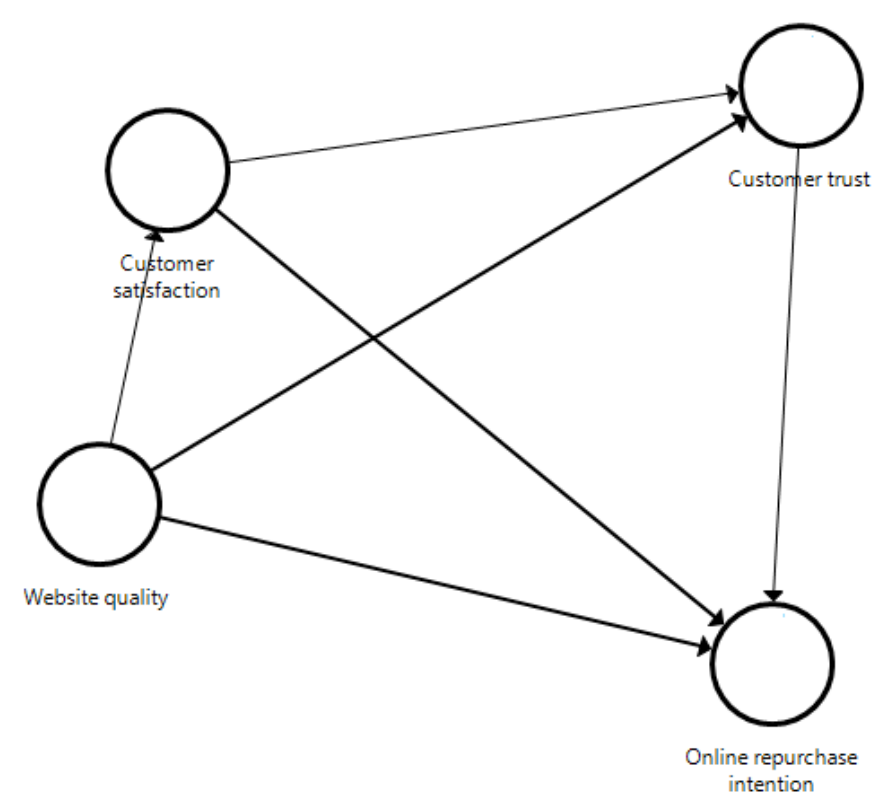

Source: Developed by authors

As described in the research model, the following hypotheses are presented:

\section{Hypothesis}

H1: Website quality has a positive effect on customer satisfaction. $\mathrm{H} 2$ : Customer satisfaction has a positive effect on customer trust. H3: Website quality has a positive effect on customer trust. 
Alvarez-Risco, Quipuzco-Chicata, and Escudero-Cipriani: Determinants of Online...

H4: Customer satisfaction has a positive effect on online repurchase intention.

H5: Customer trust has a positive effect on online repurchase intention.

H6: Website quality has a positive effect on online repurchase intention.

\section{Methodology}

\section{A. Instruments}

The questionnaire consisted of two sections. The first part collected socio-demographic information from consumers; the second used questions based on the instruments developed by Wijaya \& Farida (2018) to evaluate the factors that, according to the literature reviewed, are associated with online repurchase intention. The original items were translated and adapted linguistically. The section related to online repurchase intention and associated factors consisted of 22 items grouped into four dimensions. All the reagents are assessed through a Likert-type scale of five response options (From $1=$ completely disagree to $5=$ agree): Quality with five items, satisfaction with five items, trust with five items, and online repurchase with items. In the current study, the source of the scales is in accordance with the information in Table 1.

Table 1. Variable indicators

\begin{tabular}{lll}
\hline Variable & Item & Reference \\
\hline & $\begin{array}{l}\text { The online purchasing platforms that I use } \\
\text { give me detailed information. }\end{array}$ & $\begin{array}{l}\text { Adapted from Kim and } \\
\text { Sotel (2004) }\end{array}$ \\
\cline { 2 - 3 } & $\begin{array}{l}\text { The online purchasing platforms that I use } \\
\text { give me complete information. }\end{array}$ & $\begin{array}{l}\text { Adapted from Wijaya } \\
\text { Website }\end{array}$ \\
Quality & $\begin{array}{l}\text { The online purchasing platforms that I use } \\
\text { are interesting. }\end{array}$ & 2018) \\
& $\begin{array}{l}\text { The online purchasing platforms I use have } \\
\text { innovative designs. }\end{array}$ & \\
\hline
\end{tabular}

Continued on next page 
Table 1. Variable indicators

\begin{tabular}{|c|c|c|}
\hline Variable & Item & Reference \\
\hline & $\begin{array}{l}\text { Information can be easily found on online } \\
\text { platforms }\end{array}$ & \\
\hline \multirow{4}{*}{$\begin{array}{l}\text { Customer } \\
\text { Satisfaction }\end{array}$} & I enjoy making purchases online & $\begin{array}{l}\text { Adapted from Has- } \\
\text { sanein \& Head (2007) }\end{array}$ \\
\hline & $\begin{array}{l}\text { Interaction is convenient when I use online } \\
\text { shopping platforms. }\end{array}$ & $\begin{array}{l}\text { Adapted from Wijaya } \\
\text { \& Farida (2018) }\end{array}$ \\
\hline & $\begin{array}{l}\text { Purchasing online is a good decision to } \\
\text { Purchasing online is enjoyable. }\end{array}$ & \multirow[t]{2}{*}{$\begin{array}{l}\text { Adapted from Casaló } \\
\text { et al. (2001) }\end{array}$} \\
\hline & $\begin{array}{l}\text { I am satisfied with the whole experience of } \\
\text { purchasing online }\end{array}$ & \\
\hline \multirow[t]{4}{*}{ Customer trust } & $\begin{array}{l}\text { I believe that the companies where I am } \\
\text { purchasing online protect their customers. } \\
\text { I consider that the companies that I } \\
\text { purchase from online are honest when } \\
\text { doing business }\end{array}$ & \multirow{4}{*}{$\begin{array}{l}\text { Adapted from Gefen et } \\
\text { al. (2003) }\end{array}$} \\
\hline & I feel safe when purchasing online & \\
\hline & $\begin{array}{l}\text { I believe that the online shopping platforms } \\
\text { I use can do business online. }\end{array}$ & \\
\hline & $\begin{array}{l}\text { I am sure that the online shopping plat- } \\
\text { forms that I use are reliable. }\end{array}$ & \\
\hline \multirow{4}{*}{$\begin{array}{l}\text { Online } \\
\text { repurchase } \\
\text { intention }\end{array}$} & $\begin{array}{l}\text { When the quarantine ends, I intend to } \\
\text { continue purchasing online }\end{array}$ & $\begin{array}{l}\text { Adapted from Mire- } \\
\text { madi 2011) }\end{array}$ \\
\hline & $\begin{array}{l}\text { When the quarantine ends, I intend to } \\
\text { increase my online purchases }\end{array}$ & Authors \\
\hline & $\begin{array}{l}\text { When the quarantine ends, I intend to buy } \\
\text { instead of traditional (physical) purchasing. }\end{array}$ & $\begin{array}{l}\text { Adapted from Devaraj } \\
\text { et al. }(2002)\end{array}$ \\
\hline & $\begin{array}{l}\text { When the quarantine ends, I intend to use } \\
\text { my credit card to make online purchases }\end{array}$ & Authors \\
\hline
\end{tabular}

Continued on next page 
Alvarez-Risco, Quipuzco-Chicata, and Escudero-Cipriani: Determinants of Online...

Table 1. Variable indicators

\begin{tabular}{lll}
\hline Variable & Item & Reference \\
\hline & $\begin{array}{l}\text { When the quarantine ends, I will rec- } \\
\text { ommend my friends/family/acquaintances } \\
\text { make online purchases }\end{array}$ & $\begin{array}{l}\text { Adapted from } \\
\text { Miremadi (2011) }\end{array}$ \\
$\begin{array}{l}\text { When the quarantine ends, if my } \\
\text { friends/family/acquaintances ask me for } \\
\text { advice, I would recommend purchasing } \\
\text { online }\end{array}$ & Authors \\
$\begin{array}{l}\text { When the quarantine ends, I will not } \\
\text { purchase online }\end{array}$ & Authors \\
\hline
\end{tabular}

Source: Developed by authors

\section{Sample}

We conducted a cross-sectional online survey. The survey used in the study consisted of an online questionnaire in Google surveys sent via social media. The questionnaire was made anonymous, ensuring data confidentiality and reliability. This survey was shared in Spanish, as this is the official language in Peru. The survey was performed from May 2 to 25, 2020. Responses were collected from 371 participants. For data collection purposes consumers who agreed to participate in the study were required to respond yes/no which asked the following questions: "I have freely decided to participate in the study", "I understand that my participation is voluntary" and "I have received information about the objectives of the study". Incomplete questionnaires were rejected. The data collected was be tabulated and analyzed using the statistical programs SPSS version 26 and SmartPLS version 3.3.2 The data quality was monitored, ensuring that each response was counted only once and to discard incomplete questionnaires. The sample consisted of 371 consumers, 157 men (42.3\%) and 214 women $(57.7 \%)$, between 18 and 69 years of age. The average age was 32.44, with a standard deviation of 9.65 years. This data shows that most participants were young people. Also, $91.9 \%$ of respondents had completed tertiary education and $68.2 \%$ were single. This sample from the city of Lima in Peru has a $95 \%$ 
confidence interval and $5.09 \%$ margin of error. The description of the sample according to sociodemographic variables is presented in Table 2.

Table 2. Sociodemographic profile of the sample

\begin{tabular}{|c|c|c|}
\hline Variables & $n$ & $\%$ \\
\hline \multicolumn{3}{|l|}{ Age $X=32.44$ SD (Standard Deviation) $=9,65$} \\
\hline 18 to 25 & 84 & 22.7 \\
\hline 26 to 35 & 190 & 51.2 \\
\hline 36 to 45 & 65 & 17.5 \\
\hline 46 to 55 & 19 & 5.1 \\
\hline Older than 55 & 13 & 3.5 \\
\hline \multicolumn{3}{|l|}{ Sex } \\
\hline Male & 157 & 42.3 \\
\hline Female & 214 & 57.7 \\
\hline \multicolumn{3}{|l|}{ Marital status } \\
\hline Single & 236 & 63.6 \\
\hline Married & 78 & 21.0 \\
\hline Widower & 3 & 0.8 \\
\hline Divorced & 17 & 4.6 \\
\hline Cohabiting & 37 & 10.0 \\
\hline \multicolumn{3}{|l|}{ Income } \\
\hline 0 to 500 soles ( 0 to 150 USD) & 36 & 9.70 \\
\hline 501 to 1000 soles (approx. 151 to 300 USD) & 33 & 8.89 \\
\hline 1001 to 1500 soles (approx. 301 to 450 USD) & 41 & 11.0 \\
\hline 1501 to 2000 soles (approx. 451 to 600 USD) & 28 & 7.55 \\
\hline 2001 to 2500 soles (approx. 601 to 750 USD) & 48 & 12.95 \\
\hline 2501 to 3000 soles (approx. 751 to 900 USD) & 49 & 13.21 \\
\hline 3001 soles or more (More than 901 USD) & 136 & 36.7 \\
\hline \multicolumn{3}{|l|}{ Educational level } \\
\hline High School & 9 & 2.4 \\
\hline Technical & 36 & 9.7 \\
\hline University & 254 & 68.5 \\
\hline Postgraduate & 72 & 19.4 \\
\hline$N=371$ & & \\
\hline
\end{tabular}

Source: Calculation based in 371 respondents. 
Alvarez-Risco, Quipuzco-Chicata, and Escudero-Cipriani: Determinants of Online...

\section{B. Data analysis}

Data analysis was carried out in two stages. In the first stage, each internal consistency sub-scale was evaluated using Cronbach's alpha reliability coefficient. This coefficient indicates the degree of internal consistency between the items when their values are higher than 0.707 . The instrument's construct validity was also established through the factorial analysis of principal components with varimax rotation. In the second stage, the questionnaire was confirmed using partial least squares structural equation modeling (SEM-PLS). The SmartPLS statistical package version 3.3.2 (Ringle et al., 2015) was used to determine construct and discriminant validity and internal consistency through composite reliability. PLS usage offers a significant advantage: higher strength of the calculations in small samples; additionally, some statistical assumptions of the variables are not met (multicollinearity, different levels of measurement, non-normal distribution, and others).

When a PLS model is used, indicator reliability is assessed by examining each indicator's load and dimension, accepting as reliable those higher than 0.50 . Another measure used to analyze the model's fit is the average extracted variance that provides the variance that a construct (dimension) obtains from its indicators on error variance. A good fit requires values higher than $50 \%$. Finally, the discriminant validity of the questionnaire was established by applying the Fornell-Larcker criterion. This criterion indicates that the square root of variance extracted must be greater than the correlations presented with the rest of the subscales.

\section{Results}

\section{A. Validity and Reliability based on the TCT}

Before determining the instrument's validity and reliability, a descriptive analysis of the items and scales was conducted through the mean, standard deviation, asymmetry, and kurtosis (see Table 3). Likewise, the absence of collinearity was corroborated with VIF values (variance inflation factors), which are less than five (5). 
Table 3. Descriptive statistics: Mean, standard deviation, asymmetry, and kurtosis of the items and scale

\begin{tabular}{cccccc}
\hline Items-scales & Mean & Standard deviation & VIF & Asymmetry & Kurtosis \\
\hline P1 & 3.77 & 0.767 & 1.727 & -1.176 & 2.231 \\
P2 & 3.79 & 0.716 & 1.796 & -1.264 & 3.121 \\
P3 & 3.81 & 0.639 & 1.594 & -1.053 & 3.365 \\
P4 & 3.55 & 0.715 & 1.331 & -0.529 & 0.913 \\
P5 & 3.81 & 0.719 & 1.287 & -1.261 & 2.884 \\
P6 & 3.86 & 0.745 & 1.575 & -0.714 & 1.527 \\
P7 & 3.75 & 0.735 & 1.177 & -0.709 & 0.956 \\
P8 & 3.98 & 0.721 & 1.649 & -1.228 & 4.009 \\
P9 & 3.71 & 0.768 & 1.778 & -0.347 & 0.634 \\
P10 & 3.78 & 0.740 & 1.666 & -1.027 & 1.920 \\
P11 & 3.60 & 0.831 & 1.761 & -0.831 & 10.84 \\
P12 & 3.66 & 0.743 & 2.139 & -0.948 & 2.180 \\
P13 & 3.55 & 0.807 & 2.142 & -0.949 & 1.138 \\
P14 & 3.84 & 0.616 & 1.563 & -1.208 & 3.863 \\
P15 & 3.70 & 0.732 & 2.462 & -0.925 & 1.568 \\
P16 & 4.16 & 0.839 & 1.821 & -1.392 & 2.983 \\
P17 & 3.55 & 0.976 & 1.830 & -0.418 & -0.047 \\
P18 & 3.80 & 0.858 & 2.197 & -0.879 & 1.368 \\
P19 & 3.60 & 0.958 & 1.640 & -0.712 & 0.349 \\
P20 & 3.81 & 0.812 & 2.697 & -0.853 & 1.530 \\
P21 & 3.94 & 0.726 & 2.627 & -0.838 & 2.118 \\
\hline P16 & 3.969 & \\
\hline
\end{tabular}

Item 22 was dropped due to low value (0.345).

Source: Calculation based in 371 respondents 
Alvarez-Risco, Quipuzco-Chicata, and Escudero-Cipriani: Determinants of Online...

\section{B. Reliability}

The scales of t Website Quality, Customer Satisfaction, Customer trust, and Repurchase intention presented reliability coefficients (Cronbach's Alpha) higher than the expected minimum of (5) in exploratory analysis (see Table 4).

Table 4. Reliability of scales: Analysis of internal consistency

\begin{tabular}{lccc}
\hline Scales & $\mathrm{N}^{\circ}$ of items & Cronbach's Alpha & Range of relations item-scale \\
\hline Website quality & 5 & 0.754 & $0.643-0.783$ \\
Customer satisfaction & 5 & 0.785 & $0.528-0.809$ \\
Customer trust & 5 & 0.861 & $0.722-0.859$ \\
Online repurchase intention & $6^{*}$ & 0.878 & $0.708-0.847$ \\
\hline
\end{tabular}

Item 22 was dropped due to low value 0.345 .

Source: Calculation based in 371 respondents

\section{Validation with SEM-PLS}

To verify the validity of the instrument, with the partial least square's structural equation modeling (SEM-PLS) technique. Through the measurement model, the reliability analysis of each indicator, the internal consistency of each dimension (composite reliability), the analysis of the average variance extracted, and the discriminant validity were performed.

\section{Compound reliability}

An acceptable level of composite reliability must be greater than 0.707 . The reliability coefficients composed of the different sub-scales of the instrument oscillate between 0.836 and 0.907 (See Table 5). Overall, the values obtained in the four sub-scales confirm the reliability of the questionnaire. 
Table 5. Construct validity of the items of the scales using Structural Equations of Variance using Partial Least Squares

\section{Scale-Items}

Website Quality

The online purchase platforms that I use give me detailed information

The online purchase platforms that I use give me complete 0.752 information

The online purchase platforms that I use are interesting

The online purchase platforms I use have innovative designs

0.783

0.630

Information can be easily found on online platforms

\section{Customer Satisfaction}

I enjoy making purchasing online

0.738

Interaction is convenient when I use online shopping platforms

It is a good decision to buy online

0.528

Purchasing online is enjoyable

0.794

0.776

I am satisfied with the whole experience of online purchasing

\section{Customer trust}

I believe that the companies that I buy from online protect their

0.768 customers

I consider that the companies where I buy online are honest when 0.836 doing business

I feel safe when buying online

0.826

I believe that the online shopping platforms I use can do business 0.722 online

I am sure that the online shopping platforms that I use are reliable

0.859

Online repurchase intention (When the quarantine ends,...)

I intend to continue buying online

0.750

I intend to increase my purchase online

0.733

I intend to buy instead of traditional (physical) purchase

0.831

0.907

0.621

I intend to use my credit card to purchase online

0.708

I will recommend my friends/family/acquaintances to purchase online 0.847

if my friends/family ask me for advice, I would recommend 0.846 purchasing online

Source: Calculation based in 371 respondents. 
Alvarez-Risco, Quipuzco-Chicata, and Escudero-Cipriani: Determinants of Online...

\section{E. Discriminant validity using SEM-PLS}

For calculating the discriminant validity of the sub-scales of the questionnaire, the Fornell-Larcker criterion (1981) was used. This criterion expressed that the square root of the varian ce extracted must be greater than the correlations presented by one sub-scale with the rest of the sub-scales (Lopez-Odar et al., 2020). Table 6 shows compliance with this criterion in all sub-scales (diagonals between parentheses), demonstrating the discriminant validity of the instrument analyzed.

Table 6. Discriminant validity of sub-scales using the Fornell-Larcker criterion

\begin{tabular}{lcccc}
\hline Scales & $\begin{array}{c}\text { Customer } \\
\text { satisfaction }\end{array}$ & $\begin{array}{c}\text { Customer } \\
\text { trust }\end{array}$ & $\begin{array}{c}\text { Online } \\
\text { repurchase } \\
\text { intention }\end{array}$ & $\begin{array}{c}\text { Website } \\
\text { quality }\end{array}$ \\
\hline Customer satisfaction & $\mathbf{0 . 7 3 6}$ & & & \\
Customer trust & 0.639 & $\mathbf{0 . 8 0 4}$ & & \\
Online repurchase intention & 0.435 & 0.379 & $\mathbf{0 . 7 8 8 )}$ & $\mathbf{0 . 7 1 1}$ \\
Website quality & 0.584 & 0.598 & 0.304 & \\
\hline
\end{tabular}

Source: Calculation based in 371 respondents.

\section{Bootstrapping}

Finally, the Bootstrapping Technique (5000 times) is a non-parametric procedure applied to test if the path coefficients (beta) are significant. According to table 7 , all values are significant ( $\mathrm{p}$ values $<0.01$ ).

Also, through the calculation of the size of the effect $\left(\mathrm{F}^{2}\right)$ (Table 8$)$, it was established that Website quality has a significant direct effect on Customer satisfaction $\left(\mathrm{F}^{2}=0.584\right)$, Customer satisfaction has a significant direct effect on Customer trust $\left(\mathrm{F}^{2}=0.439\right)$, and Customer trust has a small but significant direct effect on Online repurchase intention $\left(\mathrm{F}^{2}=0.163\right)$. 
Table 7. Significance of trajectory coefficients (beta)

\begin{tabular}{lccccc}
\hline Scales & $\begin{array}{c}\text { Original } \\
\text { sample }\end{array}$ & $\begin{array}{c}\text { Mean } \\
\text { sample }\end{array}$ & $\begin{array}{c}\text { Standard } \\
\text { deviation }\end{array}$ & t-statistic & $\mathrm{p}$ \\
\hline $\begin{array}{l}\text { Customer satisfaction } \rightarrow \\
\text { Customer trust }\end{array}$ & 0.439 & 0.438 & 0.057 & 7.727 & 0.000 \\
\hline $\begin{array}{l}\text { Customer satisfaction } \rightarrow \\
\text { Online repurchase intention }\end{array}$ & 0.318 & 0.324 & 0.074 & 4.306 & 0.000 \\
\hline $\begin{array}{l}\text { Customer trust } \rightarrow \text { Online } \\
\text { repurchase intention }\end{array}$ & 0.163 & 0.160 & 0.066 & 2.459 & 0.014 \\
\hline $\begin{array}{l}\text { Website quality } \rightarrow \text { Cus- } \\
\text { tomer satisfaction }\end{array}$ & 0.584 & 0.582 & 0.060 & 9.683 & 0.000 \\
\hline $\begin{array}{l}\text { Website quality } \rightarrow \text { Cus- } \\
\text { tomer trust }\end{array}$ & 0.342 & 0.342 & 0.059 & 5.782 & 0.000 \\
\hline $\begin{array}{l}\text { Website quality } \rightarrow \text { Online } \\
\text { repurchase intention }\end{array}$ & 0.021 & 0.030 & 0.079 & 0.271 & 0.078 \\
\hline
\end{tabular}

Bootstrapping technique (5000 times) using Smart PLS. p-value $<0.01$.

Source: Calculation based in 371 respondents

Table 8. Coefficient effect size of the coefficients (beta)

\begin{tabular}{lccccc}
\hline Scales & $\begin{array}{c}\mathrm{F}^{2} \\
\text { Original } \\
\text { sample }\end{array}$ & $\begin{array}{c}\mathrm{F}^{2} \text { Mean } \\
\text { sample }\end{array}$ & $\begin{array}{c}\text { Standard } \\
\text { deviation }\end{array}$ & t-statistic & $\mathrm{p}$ \\
\hline $\begin{array}{l}\text { Customer satisfaction } \rightarrow \\
\text { Customer trust }\end{array}$ & 0.439 & 0.438 & 0.057 & 7.727 & 0.000 \\
\hline $\begin{array}{l}\text { Customer satisfaction } \rightarrow \\
\text { Online repurchase intention }\end{array}$ & 0.389 & 0.394 & 0.066 & 5.863 & 0.000 \\
\hline $\begin{array}{l}\text { Customer trust } \rightarrow \text { Online } \\
\text { repurchase intention }\end{array}$ & 0.163 & 0.160 & 0.066 & 2.459 & 0.009 \\
\hline $\begin{array}{l}\text { Website quality } \rightarrow \text { Cus- } \\
\text { tomer satisfaction }\end{array}$ & 0.584 & 0.582 & 0.060 & 9.683 & 0.000 \\
\hline $\begin{array}{l}\text { Website quality } \rightarrow \\
\text { tomer trust }\end{array}$ & 0.598 & 0.596 & 0.053 & 11.205 & 0.000 \\
\hline $\begin{array}{l}\text { Website quality } \rightarrow \text { Online } \\
\text { Repurchase intention }\end{array}$ & 0.304 & 0.314 & 0.076 & 4.007 & 0.000 \\
\hline
\end{tabular}

Bootstrapping technique (5000 times) using Smart PLS. p-value $<0.01$.

Source: Calculation based in 371 respondents. 
Alvarez-Risco, Quipuzco-Chicata, and Escudero-Cipriani: Determinants of Online...

Figure 2 show the research model tested

Figure 2. Research model tested

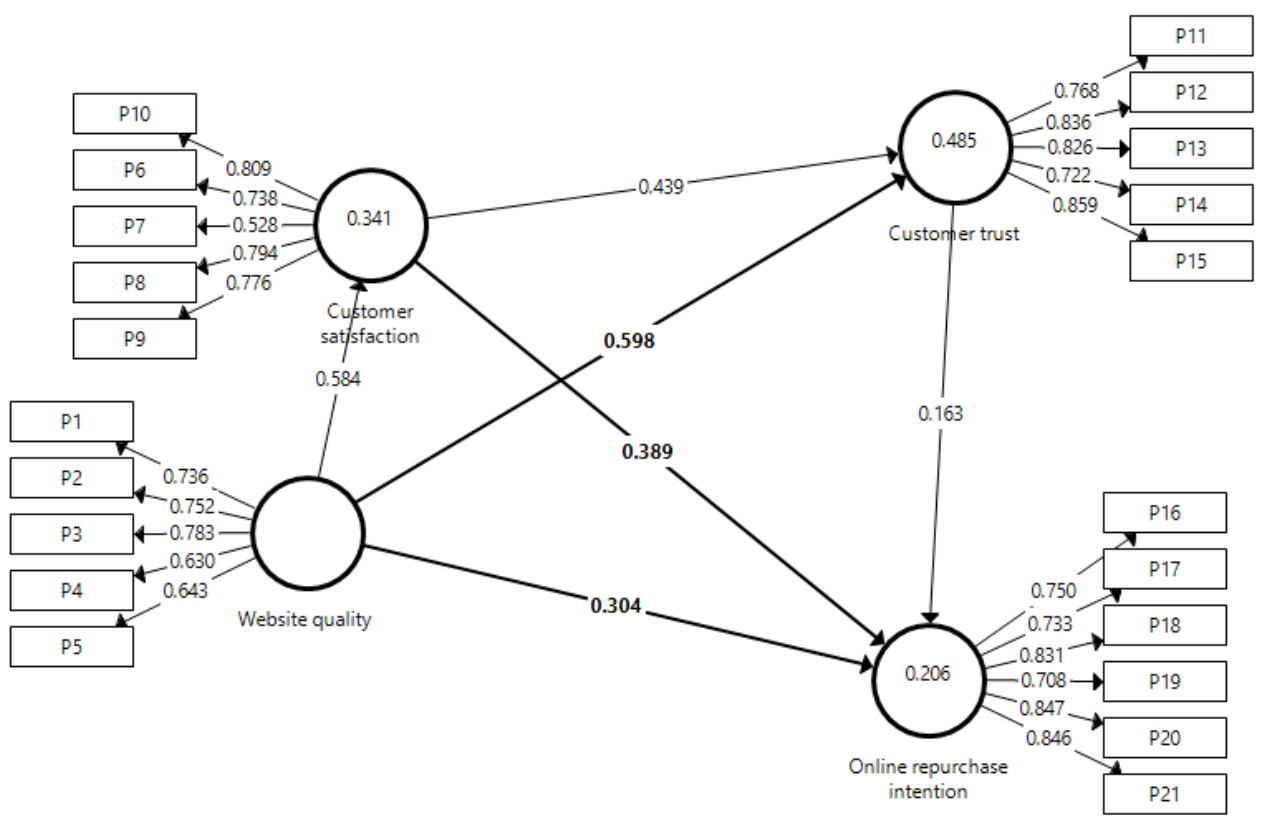

Source: Calculation based in 371 respondents.

\section{Test of Hypothesis}

H1: Website quality has a positive effect on customer satisfaction.

Website quality has a positive effect of 0.584 on customer satisfaction. Website quality explains $34.1 \%$ of customer satisfaction. The hypothesis was confirmed.

H2: Customer satisfaction has a positive effect on customer trust.

Customer satisfaction has a positive effect of 0.439 on customer trust. The hypothesis was confirmed.

H3: Website quality has a positive effect on customer trust. 
Website quality has a positive effect of 0.598 on customer trust. Website quality, together with customer satisfaction, explains $48.5 \%$ of customer trust. The hypothesis was confirmed.

H4: Customer satisfaction has a positive effect on online repurchase intention.

Customer satisfaction has a positive effect of 0.389 on online repurchase intention. The hypothesis was confirmed.

H5: Customer trust has a positive effect on online repurchase intention.

Customer trust has a positive effect of 0.163 on online repurchase intention. The hypothesis was confirmed.

\section{H6: Website quality has a positive effect on online repurchase intention.}

Website quality has a positive effect of 0.304 on online repurchase intention. The hypothesis was confirmed. Also, website quality, customer trust, and customer satisfaction explain $20.6 \%$ of the online repurchase intention.

\section{Discussion}

The present study's objective was to test the model's website quality, customer satisfaction, customer trust, and repurchase intention among Lima consumers. Discriminant validity and reliability (internal consistency - Cronbach's alpha coefficient and composite reliability) were verified. The results obtained show that the questionnaire results are valid, reliable, and statistically relevant in the application. As verified in previous studies, the scales that make up the questionnaire showed reliability and validity.

It has been possible to verify the findings previously detailed by Wang et al. (2015) and Tandon et al. (2017) about website importance in customer satisfaction. As stated before, the quality of the information displayed by companies to users is crucial in purchasing decisions (Chen \& Chang, 2018; Gao et al., 2012; Park \& Kim, 2003). The same has already been evidenced 
by Li et al. (2017) and Tandon (2020). Concerning customer satisfaction, the influence of website quality is already known (Hsu, 2008; Lin et al., 2011; Shankar et al., 2003), although for future research, it is necessary to assess which website elements are most relevant, be it the level of security, ease of use, intuitiveness when it comes to navigating among elements, etcetera. Regarding customer trust, it must be recognized that trust has been put to the test during the pandemic as, given a lack of alternatives, customers have had to initially take risks and continue buying, which differs from what GfK expressed (Gestión, 2019). Reliable information will help customers to buy more and more, which is not the sole responsibility of companies and countries' regulatory bodies, which must actively promote e-commerce and regulate for more significant and safe expansion. Finally, the study manages to show that the variables described above manage to explain repurchase intention and invites us to complete this model by including other elements that will give us a more complete understanding. During the current COVID19 pandemic, there is an emotional factor that can change preferences and lead consumers to take more risks, but this may change after the pandemic and online shopping may decrease. It is therefore urgent to ensure that other factors that explain online repurchasing are known. Following the work of Parasuraman et al. (1994), it must be borne in mind that the virtual environment, such as that seen in these times, is an amplifying factor for complaints about and recommendations for virtual companies, whether this be communicated in private messages or, more influentially, through Twitter, Instagram or Facebook. As indicated by Pee et al. (2018) and Sullivan (2018), repurchasing is reinforced by the customer environment in different sectors.

The growth of e-commerce during this pandemic has been tremendous, and there has been a significant diversification of products and services in different global sectors. However, even though e-commerce has matured significantly and has been amplified, the most fundamental aspects remain the same: website quality determines customer perception, specifically customer satisfaction, even more than the customer's final product choice does. Therefore, website design and copy should be created by professionals. This may require significant investment of money by companies and even entrepreneurs who will see a return on their investment as website quality is 
a critical aspect of online purchasing and repurchasing decisions. One aspect that has been a historical barrier for consumers has been a lack of trust in online purchases, which demonstrates the importance that consumers give to secure payment systems on business platforms (Bebber et al., 2017; Li et al., 2020; Roggeveen \& Sethuraman, 2020; Zhao et al., 2017). The current increase in e-commerce is here to stay and, in a few years', companies will have to compete to capture and retain their customers. These factors described in the present investigation are fundamental to ensure such retention in the future.

\section{Conclusions}

It is essential to understand the importance of the methodology used due to the social isolation in Peru. The research had to be carried out through online surveys, which may have led to variations in the respondents' answers. Another aspect that had an impact of the study is that many people were at home working or studying remotely due to isolation, leading to more responses. These results regarding the importance of website quality must be taken into account by companies that sell products and services over the Internet. Additionally, companies must invest more in showing themselves to be increasingly innovative for customers and to be able to generate alternative offers and forms of payment, since not all consumers want to pay by credit card or even debit card, due to the mistrust. More studies carried out in other countries are required to show if similar results are found and can be taken as a reference for the implementation of specific plans for the virtual channel.

\section{References}

Acevedo-Duque, Á., Gonzalez-Diaz, R., Vega-Muñoz, A., Fernández Mantilla, M. M., Ovalles-Toledo, L. V., \& Cachicatari-Vargas, E. (2021). The Role of B Companies in Tourism towards Recovery from the Crisis COVID-19 Inculcating Social Values and Responsible Entrepreneurship in Latin America. Sustainability, 13(14). https://doi. org/10.3390/su13147763 
Alvarez-Risco, Quipuzco-Chicata, and Escudero-Cipriani: Determinants of Online...

Afshan, G., Shahid, S., \& Tunio, M. N. (2021). Learning experiences of women entrepreneurs amidst COVID-19. International Journal of Gender and Entrepreneurship, 13(2), 162-186. https://doi.org/10.110 8/IJGE-09-2020-0153

Ahani, A., Nilashi, M., Yadegaridehkordi, E., Sanzogni, L., Tarik, A. R., Knox, K., . . . Ibrahim, O. (2019). Revealing customers' satisfaction and preferences through online review analysis: The case of Canary Islands hotels. Journal of Retailing and Consumer Services, 51, 331343. https://doi.org/10.1016/j.jretconser.2019.06.014

Ahmad, A., Rahman, O., \& Khan, M. N. (2017). Exploring the role of website quality and hedonism in the formation of e-satisfaction and e-loyalty. Journal of Research in Interactive Marketing, 11(3), 246-267. https://doi.org/10.1108/JRIM-04-2017-0022

Ahmad, Z., Jun, M., Khan, I., Abdullah, M., \& Ghauri, T. A. (2016). Examining mediating role of customer loyalty for influence of brand related attributes on customer repurchase intention. Journal of Northeast Agricultural University (English Edition), 23(2), 89-96. https://doi.org/ 10.1016/S1006-8104(16)30052-6

Al-Hasan, A., Yim, D., \& Khuntia, J. (2020). Citizens' Adherence to COVID-19 Mitigation Recommendations by the Government: A 3Country Comparative Evaluation Using Web-Based Cross-Sectional Survey Data. J. Med. Internet Res., 22(8), e20634. https://doi.org/10.2 $196 / 20634$

Allen, J., Rowan, L., \& Singh, P. (2020). Teaching and teacher education in the time of COVID-19. Asia-Pacific Journal of Teacher Education, 48(3), 233-236. https://doi.org/10.1080/1359866X.2020.1752051

Altig, D., Baker, S., Barrero, J. M., Bloom, N., Bunn, P., Chen, S., . . ., Thwaites, G. (2020). Economic uncertainty before and during the COVID-19 pandemic. Journal of Public Economics, 191, 104274. https://doi.org/10.1016/j.jpubeco.2020.104274 
Álvarez-Risco, A., Arellano, E. Z., Valerio, E. M., Acosta, N. M., \& Tarazona, Z. S. (2013). Pharmaceutical care campaign as a strategy for implementation of pharmaceutical services: Experience Peru [Article]. Pharmaceutical Care Espana, 15(1), 35-37. https://www.scopus.com/i nward/record.uri?eid=2-s2.0-84874866534\&partnerID $=40 \& \mathrm{md} 5=2$ 489c3ff3645a70c1035b8220ce51f31

Alvarez-Risco, A., \& Del-Aguila-Arcentales, S. (2021). Public Policies and Private Efforts to Increase Women Entrepreneurship Based on STEM Background. In M. Mari, S. Poggesi, \& L. Foss (Eds.), Women's Entrepreneurship in STEM Disciplines: Issues and Perspectives (pp. 75-87). Springer International Publishing. https://doi.org/10.1007/ 978-3-030-83792-1_5

Alvarez-Risco, A., Del-Aguila-Arcentales, S., \& Diaz-Risco, S. (2018). Pharmacovigilance as a tool for sustainable development of healthcare in Peru [Article]. PharmacoVigilance Review, 10(2), 4-6. https://www. scopus.com/inward/record.uri?eid=2-s2.0-85075346517\&partnerID $=40 \& \mathrm{md} 5=3 \mathrm{e} 4 \mathrm{e} 58 \mathrm{a} 75 \mathrm{a} 06 \mathrm{f} 85 \mathrm{c} 22 \mathrm{f0} 6 \mathrm{ecfe} 701 \mathrm{~d} 14 \mathrm{~b}$

Alvarez-Risco, A., Estrada-Merino, A., Anderson-Seminario, M. d. 1. M., Mlodzianowska, S., García-Ibarra, V., Villagomez-Buele, C., \& CarvacheFranco, M. (2021). Multitasking behavior in online classrooms and academic performance: case of university students in Ecuador during COVID-19 outbreak. Interactive Technology and Smart Education, 18(3), 422-434. https://doi.org/10.1108/ITSE-08-2020-0160

Alvarez-Risco, A., Estrada-Merino, A., Rosen, M. A., Vargas-Herrera, A., \& Del-Aguila-Arcentales, S. (2021). Factors for Implementation of Circular Economy in Firms in COVID-19 Pandemic Times: The Case of Peru. Environments, 8(9). https://doi.org/10.3390/environments80 90095

Alvarez-Risco, A., Mejia, C. R., Delgado-Zegarra, J., Del-Aguila-Arcentales, S., Arce-Esquivel, A. A., Valladares-Garrido, M. J., . . . Yánez, J. A. (2020). The Peru approach against the COVID-19 infodemic: Insights 
Alvarez-Risco, Quipuzco-Chicata, and Escudero-Cipriani: Determinants of Online...

and strategies [Review]. American Journal of Tropical Medicine and Hygiene, 103(2), 583-586. https://doi.org/10.4269/ajtmh.20-0536

Amoako, G. K., Kutu-Adu, S. G., Caesar, L. D., \& Neequaye, E. (2019). Relationship marketing and repurchase intention in Ghana's hospitality industry: An empirical examination of trust and commitment. Journal of Relationship Marketing, 18(2), 77-107. https://doi.org/10.1080/15 332667.2018.1534059

Apcho-Ccencho, L.-V., Cuya-Velásquez, B.-B., Alvarado Rodríguez, D., Anderson-Seminario, M. d. 1. M., Alvarez-Risco, A., Estrada-Merino, A., \& Mlodzianowska, S. (2021). The Impact of International Price on the Technological Industry in the United States and China during Times of Crisis: Commercial War and COVID-19. In K. D. Lawrence \& R. K. Klimberg (Eds.), Advances in Business and Management Forecasting (Vol. 14, pp. 149-160). Emerald Publishing Limited. https: //doi.org/10.1108/S1477-407020210000014010

Ashfaq, M., Yun, J., Waheed, A., Khan, M. S., \& Farrukh, M. (2019). Customers' expectation, satisfaction, and repurchase intention of used products online: Empirical evidence from China. SAGE Open, 9(2), 2158244019846212. https://doi.org/10.1177/2158244019846212

Azjen, I. (1980). Understanding attitudes and predicting social behavior. Englewood Cliffs. https://ci.nii.ac.jp/naid/10011527857/en/

Bai, B., Law, R., \& Wen, I. (2008). The impact of website quality on customer satisfaction and purchase intentions: Evidence from Chinese online visitors. International Journal of Hospitality Management, 27(3), 391402. https://doi.org/10.1016/j.ijhm.2007.10.008

Banerjee, D., \& Rai, M. (2020). Social isolation in Covid-19: The impact of loneliness. International Journal of Social Psychiatry, 66(6), 525-527. https://doi.org/10.1177/0020764020922269

BBC. (2020). Coronavirus en América Latina: 8 oportunidades de negocios digitales en medio de la pandemia. https://www.bbc.com/mundo/noti cias-53478617 
Bebber, S., Milan, G. S., De Toni, D., Eberle, L., \& Slongo, L. A. (2017). Antecedents of purchase intention in the online context. Journal of Relationship Marketing, 16(1), 82-98. https://doi.org/10.1080/153326 67.2016.1242396

Belwal, R., Al Shibli, R., \& Belwal, S. (2020). Consumer protection and electronic commerce in the Sultanate of Oman. Journal of Information, Communication and Ethics in Society, 19(1), 38-60. https://doi.org/10 .1108/JICES-09-2019-0110

Berg-Weger, M., \& Morley, J. E. (2020). Loneliness and social isolation in older adults during the COVID-19 pandemic: Implications for gerontological social work. The journal of nutrition, health \& aging, 24(5), 456-458. https://doi.org/10.1007/s12603-020-1366-8

Berry, L. L., Danaher, T. S., Aksoy, L., \& Keiningham, T. L. (2020). Service safety in the pandemic age. Journal of Service Research, 23(4), 391-395. https://doi.org/10.1177/1094670520944608

Brouder, P. (2020). Reset redux: possible evolutionary pathways towards the transformation of tourism in a COVID-19 world. Tourism Geographies, 22(3), 484-490. https://doi.org/10.1080/14616688.2020.1760928

Buttenheim, A. M., Paz-Soldán, V. A., Castillo-Neyra, R., Toledo Vizcarra, A. M., Borrini-Mayori, K., McGuire, M., . . . Levy, M. Z. (2018). Increasing participation in a vector control campaign: a cluster randomised controlled evaluation of behavioural economic interventions in Peru. BMJ Global Health, 3(5), e000757. https://doi. org/10.1136/bmjgh-2018-000757

Carvache-Franco, M., Alvarez-Risco, A., Carvache-Franco, W., CarvacheFranco, O., Estrada-Merino, A., \& Rosen, M. A. (2021). Coastal Cities Seen from Loyalty and Their Tourist Motivations: A Study in Lima, Peru. Sustainability, 13(21). https://doi.org/10.3390/su132111575

Chafloque-Cespedes, R., Alvarez-Risco, A., Robayo-Acuña, P.-V., GamarraChavez, C.-A., Martinez-Toro, G.-M., \& Vicente-Ramos, W. (2021). Effect of Sociodemographic Factors in Entrepreneurial Orientation and 
Alvarez-Risco, Quipuzco-Chicata, and Escudero-Cipriani: Determinants of Online...

Entrepreneurial Intention in University Students of Latin American Business Schools. In P. Jones, N. Apostolopoulos, A. Kakouris, C. Moon, V. Ratten, \& A. Walmsley (Eds.), Universities and Entrepreneurship: Meeting the Educational and Social Challenges (Vol. 11, pp. 151-165). Emerald Publishing Limited. https://doi.org/10.110 8/S2040-724620210000011010

Chen, C.-C., \& Chang, Y.-C. (2018). What drives purchase intention on Airbnb? Perspectives of consumer reviews, information quality, and media richness. Telematics and Informatics, 35(5), 1512-1523. https: //doi.org/10.1016/j.tele.2018.03.019

Chen, C.-C. V., \& Chen, C.-J. (2017). The role of customer participation for enhancing repurchase intention. Management Decision, 55(3), 547-562. https://doi.org/10.1108/MD-06-2016-0380

Chen, X., Zhang, S. X., Jahanshahi, A. A., Alvarez-Risco, A., Dai, H., Li, J., \& Ibarra, V. G. (2020). Belief in a COVID-19 conspiracy theory as a predictor of mental health and well-being of health care workers in Ecuador: Cross-sectional survey study [Article]. JMIR Public Health and Surveillance, 6(3), Article e20737. https://doi.org/10.2196/20737

Chiu, C. M., Chang, C. C., Cheng, H. L., \& Fang, Y. H. (2009). Determinants of customer repurchase intention in online shopping. Online Information Review, 33(4), 761-784. https://doi.org/10.110 8/14684520910985710

Chou, S., \& Chen, C.-W. (2018). The influences of relational benefits on repurchase intention in service contexts: the roles of gratitude, trust and commitment. Journal of Business \& Industrial Marketing, 33(5), 680692. https://doi.org/10.1108/JBIM-08-2017-0187

Curina, I., Francioni, B., Hegner, S. M., \& Cioppi, M. (2020). Brand hate and non-repurchase intention: A service context perspective in a crosschannel setting. Journal of Retailing and Consumer Services, 54, 102031. https://doi.org/10.1016/j.jretconser.2019.102031

Daniel, S. J. (2020). Education and the COVID-19 pandemic. PROSPECTS, 49(1), 91-96. https://doi.org/10.1007/s11125-020-09464-3 
Das, G. (2014). Linkages of retailer personality, perceived quality and purchase intention with retailer loyalty: A study of Indian non-food retailing. Journal of Retailing and Consumer Services, 21(3), 407-414. https://doi.org/10.1016/j.jretconser.2013.11.001

Dehghan, N. A., Alizadeh, H., \& Mirzaei-Alamouti, S. (2015). A study on the effects of customer value and perceived value on customer satisfaction, brand loyalty and pepurchase intention. Serbian Journal of Management, 10(2), 173-188. https://doi.org/10.5937/sjm10-7844

Duarte Alonso, A., Kok, S. K., Bressan, A., O'Shea, M., Sakellarios, N., Koresis, A., . . Santoni, L. J. (2020). COVID-19, aftermath, impacts, and hospitality firms: An international perspective. International Journal of Hospitality Management, 91, 102654. https://doi.org/10 .1016/j.ijhm.2020.102654

Enciso-Zarate, A., Guzmán-Oviedo, J., Sánchez-Cardona, F., Martínez-Rohenes, D., Rodríguez-Palomino, J. C., Alvarez-Risco, A., . . . Diaz-Risco, S. (2016). Evaluation of contamination by cytotoxic agents in colombian hospitals [Article]. Pharmaceutical Care Espana, 18(6), 241-250. https: //www.scopus.com/inward/record.uri?eid=2-s2.0-85016354632\&par tnerID=40\&md5=91b92018b91cec2dc38de2f2641678b3

Evans, O. (2019). Repositioning for increased digital dividends: Internet usage and economic well-being in Sub-Saharan Africa. Journal of Global Information Technology Management, 22(1), 47-70. https://doi.org/10 .1080/1097198X.2019.1567218

Fang, Y., Qureshi, I., Sun, H., McCole, P., Ramsey, E., \& Lim, K. H. (2014). Trust, satisfaction, and online repurchase intention

the moderating role of perceived effectiveness of E-Commerce institutional mechanisms. MIS Quarterly, 38(2), 407-A409. https://www.jstor.org/ stable/26634932

Fang, Y. H., Chiu, C. M., \& Wang, E. T. G. (2011). Understanding customers' satisfaction and repurchase intentions. Internet Research, 21(4), 479-503. https://doi.org/10.1108/10662241111158335 
Alvarez-Risco, Quipuzco-Chicata, and Escudero-Cipriani: Determinants of Online...

Faraoni, M., Rialti, R., Zollo, L., \& Pellicelli, A. C. (2019). Exploring eloyalty antecedents in B2C e-commerce. British Food Journal, 121(2), 574-589. https://doi.org/10.1108/BFJ-04-2018-0216

Fotiadis, A., Polyzos, S., \& Huan, T.-C. T. C. (2021). The good, the bad and the ugly on COVID-19 tourism recovery. Annals of Tourism Research, 87, 103117. https://doi.org/10.1016/j.annals.2020.103117

Gao, J., Zhang, C., Wang, K., \& Ba, S. (2012). Understanding online purchase decision making: The effects of unconscious thought, information quality, and information quantity. Decision Support Systems, 53(4), 772-781. https://doi.org/10.1016/j.dss.2012.05.011

Gao, X., Shi, X., Guo, H., \& Liu, Y. (2020). To buy or not buy food online: The impact of the COVID-19 epidemic on the adoption of e-commerce in China. PLOS ONE, 15(8), e0237900. https://doi.org/10.1371/jour nal.pone. 0237900

Gawor, T., \& Hoberg, K. (2019). Customers' valuation of time and convenience in e-fulfillment. International Journal of Physical Distribution \& Logistics Management, 49(1), 75-98. https://doi.org/10.1108/IJPDLM -09-2017-0275

Gestión. (2019). GfK: Why are Peruvians afraid of buying online? [GfK: ¿`or qué los peruanos tienen miedo a comprar en internet?]. https://gestion. pe/economia/gfk-peruanos-miedo-comprar-internet-260721-noticia/

Gostin, L. O., \& Wiley, L. F. (2020). Governmental public health powers during the COVID-19 pandemic: Stay-at-home orders, business closures, and travel restrictions. JAMA, 323(21), 2137-2138. https: //doi.org/10.1001/jama.2020.5460

Guo, H., \& Gao, S. (2017, 2017//). Barriers to adopting e-commerce in Chinese rural areas: A case study. Digital Nations - Smart Cities, Innovation, and Sustainability, Cham.

Hellier, P. K., Geursen, G. M., Carr, R. A., \& Rickard, J. A. (2003). Customer repurchase intention. European Journal of Marketing, 37(11/12), 1762 1800. https://doi.org/10.1108/03090560310495456 
Hsu, S. H. (2008). Developing an index for online customer satisfaction: Adaptation of American Customer Satisfaction Index. Expert Systems with Applications, 34(4), 3033-3042. https://doi.org/10.1016/j.eswa.2 007.06.036

Huang, S.-L., \& Chang, Y.-C. (2019). Cross-border e-commerce: consumers' intention to shop on foreign websites. Internet Research, 29(6), 12561279. https://doi.org/10.1108/INTR-11-2017-0428

Huarng, K.-H., \& Yu, T. H.-K. (2011). Internet software and services: past and future. The Service Industries Journal, 31(1), 79-89. https://doi.org/ 10.1080/02642069.2010.485193

Hwang, T.-J., Rabheru, K., Peisah, C., Reichman, W., \& Ikeda, M. (2020). Loneliness and social isolation during the COVID-19 pandemic. International Psychogeriatrics, 32(10), 1217-1220. https://doi.org/10 .1017/S1041610220000988

ILO. (2020). COVID-19 and the world of work. https://www.ilo.org/global /topics/coronavirus/lang--en/index.htm

Jin, M., Li, G., \& Cheng, T. C. E. (2018). Buy online and pick up in-store: Design of the service area. European Journal of Operational Research, 268(2), 613-623. https://doi.org/10.1016/j.ejor.2018.02.002

Kang, J.-W., \& Namkung, Y. (2019). The information quality and source credibility matter in customers' evaluation toward food $\mathrm{O} 2 \mathrm{O}$ commerce. International Journal of Hospitality Management, 78, 189198. https://doi.org/10.1016/j.ijhm.2018.10.011

Kaya, B., Behravesh, E., Abubakar, A. M., Kaya, O. S., \& Orús, C. (2019). The moderating role of website familiarity in the relationships between eservice quality, e-satisfaction and e-loyalty. Journal of Internet Commerce, 18(4), 369-394. https://doi.org/10.1080/15332861.2019.1668658

Kim, H., \& Niehm, L. S. (2009). The impact of website quality on information quality, value, and loyalty intentions in apparel retailing. Journal of Interactive Marketing, 23(3), 221-233. https://doi.org/10.1 016/j.intmar.2009.04.009 
Alvarez-Risco, Quipuzco-Chicata, and Escudero-Cipriani: Determinants of Online...

Lazo-Porras, M., Perez-Leon, S., Cardenas, M. K., Pesantes, M. A., Miranda, J. J., Suggs, L. S., . . . Beran, D. (2020). Lessons learned about cocreation: developing a complex intervention in rural Peru. Global Health Action, 13(1), 1754016. https://doi.org/10.1080/16549716 .2020 .1754016

Lee, Y., \& Kozar, K. A. (2006). Investigating the effect of website quality on e-business success: An analytic hierarchy process (AHP) approach. Decision Support Systems, 42(3), 1383-1401. https://doi.org/10.1016/j. dss.2005.11.005

Leiva-Martinez, M.-A., Anderson-Seminario, M. d. 1. M., Alvarez-Risco, A., Estrada-Merino, A., \& Mlodzianowska, S. (2021). Price Variation in Lower Goods as of Previous Economic Crisis and the Contrast of the Current Price Situation in the Context of COVID-19 in Peru. In K. D. Lawrence \& R. K. Klimberg (Eds.), Advances in Business and Management Forecasting (Vol. 14, pp. 161-166). Emerald Publishing Limited. https://doi.org/10.1108/S1477-407020210000014011

Li, L., Peng, M., Jiang, N., \& Law, R. (2017). An empirical study on the influence of economy hotel website quality on online booking intentions. International Journal of Hospitality Management, 63, 1-10. https://doi.org/10.1016/j.ijhm.2017.01.001

Li, Z., Sha, Y., Song, X., Yang, K., Zhao, K., Jiang, Z., \& Zhang, Q. (2020). Impact of risk perception on customer purchase behavior: a meta-analysis. Journal of Business \& Industrial Marketing, 35(1), 76-96. https://doi.org/10.1108/JBIM-12-2018-0381

Liang, C.-J., \& Chen, H.-J. (2009). A study of the impacts of website quality on customer relationship performance. Total Quality Management \& Business Excellence, 20(9), 971-988. https://doi.org/10.1080/147833 60903181784

Liang, L. J., Choi, H. C., \& Joppe, M. (2018). Exploring the relationship between satisfaction, trust and switching intention, repurchase intention in the context of Airbnb. International Journal of Hospitality Management, 69, 41-48. https://doi.org/10.1016/j.ijhm.2017.10.015 
Liao, C., Lin, H.-N., Luo, M. M., \& Chea, S. (2017). Factors influencing online shoppers' repurchase intentions: The roles of satisfaction and regret. Information \& Management, 54(5), 651-668. https://doi.org/ 10.1016/j.im.2016.12.005

Lim, X.-J., Cheah, J.-H., Waller, D. S., Ting, H., \& Ng, S. I. (2019). What s-commerce implies? Repurchase intention and its antecedents. Marketing Intelligence \& Planning, 38(6), 760-776. https://doi.org/10 .1108/MIP-03-2019-0145

Lin, C.-C., Wu, H.-Y., \& Chang, Y.-F. (2011). The critical factors impact on online customer satisfaction. Procedia Computer Science, 3, 276-281. https://doi.org/10.1016/j.procs.2010.12.047

Liu, Y., \& Tang, X. (2018). The effects of online trust-building mechanisms on trust and repurchase intentions. Information Technology \& People, 31(3), 666-687. https://doi.org/10.1108/ITP-10-2016-0242

Lopez-Odar, D., Alvarez-Risco, A., Vara-Horna, A., Chafloque-Cespedes, R., \& Sekar, M. C. (2020). Validity and reliability of the questionnaire that evaluates factors associated with perceived environmental behavior and perceived ecological purchasing behavior in Peruvian consumers. Social Responsibility Journal, 16(3), 403-417. https://doi.org/10.1108/SRJ08-2018-0201

Ma, J., Lu, Y., \& Gupta, S. (2019). User innovation evaluation: Empirical evidence from an online game community. Decision Support Systems, 117, 113-123. https://doi.org/10.1016/j.dss.2018.11.003

Machida, M., Nakamura, I., Saito, R., Nakaya, T., Hanibuchi, T., Takamiya, T., . . Inoue, S. (2020). Adoption of personal protective measures by ordinary citizens during the COVID-19 outbreak in Japan. International Journal of Infectious Diseases, 94, 139-144. https://doi.or g/10.1016/j.ijid.2020.04.014

Mayer, R. C., Davis, J. H., \& Schoorman, F. D. (1995). An integrative model of organizational trust. Academy of Management Review, 20(3), 709-734. https://doi.org/10.5465/amr.1995.9508080335 
Alvarez-Risco, Quipuzco-Chicata, and Escudero-Cipriani: Determinants of Online...

Meilatinova, N. (2021). Social commerce: Factors affecting customer repurchase and word-of-mouth intentions. International Journal of Information Management, 57, 102300. https://doi.org/10.1016/j.ij infomgt.2020.102300

Mejía-Acosta, N., Alvarez-Risco, A., Solís-Tarazona, Z., Matos-Valerio, E., Zegarra-Arellano, E., \& Del-Aguila-Arcentales, S. (2016). Adverse drug reactions reported as a result of the implementation of pharmaceutical care in the Institutional Pharmacy DIGEMID - Ministry of Health [Article]. Pharmaceutical Care Espana, 18(2), 67-74. https://www.sc opus.com/inward/record.uri?eid=2-s2.0-84992258599\&partnerID=4 $0 \& \mathrm{md} 5=\mathrm{ff} 6478 \mathrm{e} 7107286 \mathrm{e} 30 \mathrm{fb} 4 \mathrm{cbddcb} 20 \mathrm{eebc}$

Nguyen, D. H., de Leeuw, S., Dullaert, W., \& Foubert, B. P. J. (2019). What is the right delivery option for you? Consumer preferences for delivery attributes in online retailing. Journal of Business Logistics, 40(4), 299321. https://doi.org/10.1111/jbl.12210

Parasuraman, A., Zeithaml, V. A., \& Berry, L. L. (1994). Reassessment of expectations as a comparison standard in measuring service quality: Implications for further research. Journal of Marketing, 58(1), 111-124. https://doi.org/10.1177/002224299405800109

Park, C. H., \& Kim, Y. G. (2003). Identifying key factors affecting consumer purchase behavior in an online shopping context. International Journal of Retail \& Distribution Management, 31(1), 16-29. https://doi.org/ $10.1108 / 09590550310457818$

Pee, L. G., Jiang, J., \& Klein, G. (2018). Signaling effect of website usability on repurchase intention. International Journal of Information Management, 39, 228-241. https://doi.org/10.1016/j.ijinfomgt.2017 .12 .010

Pham, Q. T., Tran, X. P., Misra, S., Maskeliūnas, R., \& Damaševičius, R. (2018). Relationship between convenience, perceived value, and repurchase intention in online shopping in Vietnam. Sustainability, 10(1). https://doi.org/10.3390/su10010156 
Prasetyo, Y. T., Tanto, H., Mariyanto, M., Hanjaya, C., Young, M. N., Persada, S. F., . . . Redi, A. A. (2021). Factors affecting customer satisfaction and loyalty in online food delivery service during the COVID-19 pandemic: Its relation with open innovation. Journal of Open Innovation: Technology, Market, and Complexity, 7(1). https: //doi.org/10.3390/joitmc7010076

Qazi, A., Tamjidyamcholo, A., Raj, R. G., Hardaker, G., \& Standing, C. (2017). Assessing consumers' satisfaction and expectations through online opinions: Expectation and disconfirmation approach. Computers in Human Behavior, 75, 450-460. https://doi.org/10.1016/j.chb.2017 .05 .025

Quispe-Cañari, J. F., Fidel-Rosales, E., Manrique, D., Mascaró-Zan, J., Huamán-Castillón, K. M., Chamorro-Espinoza, S. E., . . Mejia, C. R. (2021). Self-medication practices during the COVID-19 pandemic among the adult population in Peru: A cross-sectional survey [Article]. Saudi Pharmaceutical Journal, 29(1), 1-11. https://doi.org/10.1016/j. jsps.2020.12.001

Rahman, S. u., Khan, M. A., \& Iqbal, N. (2018). Motivations and barriers to purchasing online: understanding consumer responses. South Asian Journal of Business Studies, 7(1), 111-128. https://doi.org/10.1108/SA JBS-11-2016-0088

Rastogi, A., \& Mehrotra, M. (2017). Opinion spam detection in online reviews. Journal of Information \& Knowledge Management, 16(04), 1750036. https://doi.org/10.1142/S0219649217500368

Razai, M. S., Oakeshott, P., Kankam, H., Galea, S., \& Stokes-Lampard, H. (2020). Mitigating the psychological effects of social isolation during the covid-19 pandemic. BMJ, 369, m1904. https://doi.org/10.1136/ bmj.m1904

Rodríguez, R., Svensson, G., Román, S., \& Wood, G. (2018). Teleological sales and purchase approaches in complex business relationships customers' expectations before and perceptions after purchase. Journal 
Alvarez-Risco, Quipuzco-Chicata, and Escudero-Cipriani: Determinants of Online...

of Business \& Industrial Marketing, 33(4), 523-538. https://doi.org/10 .1108/JBIM-11-2016-0262

Roggeveen, A. L., \& Sethuraman, R. (2020). Customer-Interfacing retail technologies in 2020 \& beyond: An integrative framework and research directions. Journal of Retailing, 96(3), 299-309. https://doi.org/10.101 6/j.jretai.2020.08.001

Rojas-Osorio, M., Alvarez-Risco, A. (2019). Intention to use smartphones among Peruvian university students. International Journal of Interactive Mobile Technologies (iJIM), 13(3), 40-52.

Rojas Román, B., Moscoso, S., Chung, S. A., Limpias Terceros, B., ÁlvarezRisco, A., \& Yáñez, J. A. (2020). Tratamiento de la COVID-19 en Perú y Bolivia y los riesgos de la automedicación [COVID-19; tratamiento; estrategia; fármacos; automedicación; Perú; Bolivia.]. 2020, 53(2). http: //www.revfarmacia.sld.cu/index.php/far/article/view/435/351

Savila, I. D., Wathoni, R. N., \& Santoso, A. S. (2019). The role of multichannel integration, trust and offline-to-online customer loyalty towards repurchase intention: an empirical study in online-to-offline (O2O) e-commerce. Procedia Computer Science, 161, 859-866. https: //doi.org/10.1016/j.procs.2019.11.193

Shankar, V., Smith, A. K., \& Rangaswamy, A. (2003). Customer satisfaction and loyalty in online and offline environments. International Journal of Research in Marketing, 20(2), 153-175. https://doi.org/10.1016/S016 7-8116(03)00016-8

Sharif, A., Aloui, C., \& Yarovaya, L. (2020). COVID-19 pandemic, oil prices, stock market, geopolitical risk and policy uncertainty nexus in the US economy: Fresh evidence from the wavelet-based approach. International Review of Financial Analysis, 70, 101496. https://doi.org/ 10.1016/j.irfa.2020.101496

Sharma, M., Gupta, M., \& Joshi, S. (2019). Adoption barriers in engaging young consumers in the Omni-channel retailing. Young Consumers, 21(2), 193-210. https://doi.org/10.1108/YC-02-2019-0953 
Shin, J. I., Chung, K. H., Oh, J. S., \& Lee, C. W. (2013). The effect of site quality on repurchase intention in Internet shopping through mediating variables: The case of university students in South Korea. International Journal of Information Management, 33(3), 453-463. http s://doi.org/10.1016/j.ijinfomgt.2013.02.003

Singh, S., \& Jang, S. (2020). Search, purchase, and satisfaction in a multiplechannel environment: How have mobile devices changed consumer behaviors? Journal of Retailing and Consumer Services, 102200. https: //doi.org/10.1016/j.jretconser.2020.102200

Slack, N., Singh, G., \& Sharma, S. (2020). The effect of supermarket service quality dimensions and customer satisfaction on customer loyalty and disloyalty dimensions. International Journal of Quality and Service Sciences, 12(3), 297-318. https://doi.org/10.1108/IJQSS-10-2019-0114

Solimun, S., \& Fernandes, A. A. R. (2018). The mediation effect of customer satisfaction in the relationship between service quality, service orientation, and marketing mix strategy to customer loyalty. Journal of Management Development, 37(1), 76-87. https://doi.org/10.1108/JM D-12-2016-0315

Song, P., Wang, Q., Liu, H., \& Li, Q. (2020). The value of buy-onlineand-pickup-in-store in Omni-channel: Evidence from customer usage data. Production and Operations Management, 29(4), 995-1010. https: //doi.org/10.1111/poms.13146

Stouthuysen, K., Teunis, I., Reusen, E., \& Slabbinck, H. (2018). Initial trust and intentions to buy: The effect of vendor-specific guarantees, customer reviews and the role of online shopping experience. Electronic Commerce Research and Applications, 27, 23-38. https://doi.org/10.101 6/j.elerap.2017.11.002

Sullivan, Y. W., \& Kim, D. J. (2018). Assessing the effects of consumers' product evaluations and trust on repurchase intention in e-commerce environments. International Journal of Information Management, 39, 199-219. https://doi.org/10.1016/j.ijinfomgt.2017.12.008 
Alvarez-Risco, Quipuzco-Chicata, and Escudero-Cipriani: Determinants of Online...

Tan, H., Lv, X., Liu, X., \& Gursoy, D. (2018). Evaluation nudge: Effect of evaluation mode of online customer reviews on consumers preferences. Tourism Management, 65, 29-40. https://doi.org/10.1016/j.tourman. 2017.09.011

Tandon, U., Kiran, R., \& Sah, A. N. (2017). Customer satisfaction as mediator between website service quality and repurchase intention: An emerging economy case. Service Science, 9(2), 106-120. https://doi.or g/10.1287/serv.2016.0159

Tandon, U., Mittal, A., \& Manohar, S. (2020). Examining the impact of intangible product features and e-commerce institutional mechanics on consumer trust and repurchase intention. Electronic Markets. https: //doi.org/10.1007/s12525-020-00436-1

Theoret, C., \& Ming, X. (2020). Our education, our concerns: The impact on medical student education of COVID-19. Medical Education, 54(7), 591-592. https://doi.org/10.1111/medu.14181

Trivedi, S. K., \& Yadav, M. (2020). Repurchase intentions in Y generation: mediation of trust and e-satisfaction. Marketing Intelligence \& Planning, 38(4), 401-415. https://doi.org/10.1108/MIP-02-2019-0072

Valarezo, Á., Pérez-Amaral, T., Garín-Muñoz, T., Herguera García, I., \& López, R. (2018). Drivers and barriers to cross-border e-commerce: Evidence from Spanish individual behavior. Telecommunications Policy, 42(6), 464-473. https://doi.org/10.1016/j.telpol.2018.03.006

van Stekelenburg, A., Schaap, G., Veling, H., \& Buijzen, M. (2021). Investigating and Improving the Accuracy of US Citizens' Beliefs About the COVID-19 Pandemic: Longitudinal Survey Study. J. Med. Internet Res., 23(1), e24069. https://doi.org/10.2196/24069

Ventre, I., \& Kolbe, D. (2020). The impact of perceived usefulness of online reviews, Trust and perceived risk on online purchase intention in emerging markets: A Mexican perspective. Journal of International Consumer Marketing, 32(4), 287-299. https://doi.org/10.1080/0896 1530.2020.1712293 
Wang, L., Law, R., Guillet, B. D., Hung, K., \& Fong, D. K. C. (2015). Impact of hotel website quality on online booking intentions: eTrust as a mediator. International Journal of Hospitality Management, 47, 108115. https://doi.org/10.1016/j.ijhm.2015.03.012

Wang, M.-Y., Zhang, P.-Z., Zhou, C.-Y., \& Lai, N.-Y. (2019). Effect of emotion, expectation, and privacy on purchase intention in WeChat health product consumption: The mediating role of trust. International Journal of Environmental Research and Public Health, 16(20). https: //doi.org/10.3390/ijerph16203861

Wells, J. D., Valacich, J. S., \& Hess, T. J. (2011). What signal are you sending? How website quality influences perceptions of product quality and purchase intentions. MIS Quarterly, 35(2), 373-396. https://doi.or g/10.2307/23044048

WHO. (2021). WHO Coronavirus Disease (COVID-19) Dashboard. https: //covid19.who.int

Wu, W.-Y., \& Chang, M.-L. (2007). The role of risk attitude on online shopping: experience, customer satisfaction, and repurchase intention. Social Behavior and Personality: an international journal, 35(4), 453468. https://doi.org/10.2224/sbp.2007.35.4.453

Yan, J., Kim, S., Zhang, S. X., Foo, M.-D., Alvarez-Risco, A., Del-AguilaArcentales, S., \& Yáńez, J. A. (2021). Hospitality workers' COVID-19 risk perception and depression: A contingent model based on transactional theory of stress model. International Journal of Hospitality Management, 95, 102935. https://doi.org/10.1016/j.ijhm.2021.102935

Yáñez, J. A., Jahanshahi, A. A., Alvarez-Risco, A., Li, J., \& Zhang, S. X. (2020). Anxiety, distress, and turnover intention of healthcare workers in Peru by their distance to the epicenter during the COVID-19 crisis [Article]. American Journal of Tropical Medicine and Hygiene, 103(4), 1614-1620. https://doi.org/10.4269/ajtmh.20-0800

Yi, Y., \& La, S. (2004). What influences the relationship between customer satisfaction and repurchase intention? Investigating the effects of 
adjusted expectations and customer loyalty. Psychology \& Marketing, 21(5), 351-373. https://doi.org/10.1002/mar.20009

Zhang, S. X., Chen, J., Afshar Jahanshahi, A., Alvarez-Risco, A., Dai, H., Li, J., \& Patty-Tito, R. M. (2021). Succumbing to the COVID-19 pandemic-healthcare workers not satisfied and intend to leave their jobs [Article]. International Journal of Mental Health and Addiction. https://doi.org/10.1007/s11469-020-00418-6

Zhang, S. X., Sun, S., Afshar Jahanshahi, A., Alvarez-Risco, A., Ibarra, V. G., Li, J., \& Patty-Tito, R. M. (2020). Developing and testing a measure of COVID-19 organizational support of healthcare workers - results from Peru, Ecuador, and Bolivia [Article]. Psychiatry Research, 291, Article 113174. https://doi.org/10.1016/j.psychres.2020.113174

Zhao, X., Deng, S., \& Zhou, Y. (2017). The impact of reference effects on online purchase intention of agricultural products. Internet Research, 27(2), 233-255. https://doi.org/10.1108/IntR-03-2016-0082

Zhao, Y., Wen, L., Feng, X., Li, R., \& Lin, X. (2020). How managerial responses to online reviews affect customer satisfaction: An empirical study based on additional reviews. Journal of Retailing and Consumer Services, 57, 102205. https://doi.org/10.1016/j.jretconser.2020.102205

Zhu, W., Mou, J., \& Benyoucef, M. (2019). Exploring purchase intention in cross-border E-commerce: A three stage model. Journal of Retailing and Consumer Services, 51, 320-330. https://doi.org/10.1016/j.jretconser.2 019.07.004 